\title{
ALTERNATIVE VISIONS OF LEGAL BIOGRAPHY: AN ABSTRACT
}

Biography is booming. Shakespeare, Pepys, Jane Austen, Steve Jobs and Billy Conolly, for example, have all been the subject of recent biographies that have sold millions, as have celebrity biographies and autobiographies.

While political biographies are not in same league sales-wise, they remain popular ${ }^{1}$. Artists, philosophers, historians and even economists, from Bagehot and Beveridge to Warhol and Wittgenstein, have all attracted a steady stream of high quality biographies, that have impacted on both academic and lay consciousness.

At first blush, the contrast with legal biography in Britain is striking. The once popular biographies of illustrious lawyers and judges, typified by Marjoribanks biography of Marshall Hall ${ }^{2}$ and Lewis' biographies of Lords Atkin and Hailsham ${ }^{3}$, appear to be in decline. Apparently they are selling less, and certainly fewer are published today than in the previous two hundred years. Perhaps contemporary lawyers and judges are less colourful, lack the popular notoriety and have become more narrowly professional than their counterparts of yore? Perhaps they have been eclipsed by a different notion of "celebrity", publication and the media?

One could also point to the invidious comparison between the quantity and quality of legal biography in, say, contemporary Canada and the USA relative to Britain. While the best of legal life writing harnesses historical empathy with a commitment to the careful and conscious scrutiny of the past, the worst tends towards hagiography.

However, change is in the air. High-quality British academic legal biography, pioneered by Heuston and Stevens in the 1960's and '70's, has grown and established a small, marginal, but discernible niche in the world of scholarship,

\footnotetext{
${ }^{1}$ Margaret Thatcher, Mao, Indira Gandhi, Churchill, Harold Wilson and the Queen are just some of those who are the subject of recent best-selling biographies.

${ }^{2}$ E. Marjoribanks, Famous Trials of Marshall Hall (London: Penguin, 1989).

${ }^{3}$ G. Lewis, Lord Hailsham: A Life (London: Pimlico, 1998) and Lord Atkin (Oxford: Hart, 1999).
} 
albeit, a precarious one ${ }^{4}$. Work illustrative of this biographical turn includes

Auchmuty on Gwyneth Bebb, Beatson and Zimmermann on German-speaking

émigré lawyers in twentieth century Britain, Dukes on Kahn-Freund, Duxbury on

Pollock, Lacey on Hart, Parry on Hughes Parry and Prest on Blackstone ${ }^{5}$.

Institutional initiatives at $\operatorname{LSE}^{6}$ and Cambridge ${ }^{7}$, for example, also indicate that a

struggle is under way to sustain legal biography in Britain as never before. Thus, we

may be witnessing a turning point, although only time will tell.

To date, the bulk of legal biographies have focused on the lives of the elite; most often white, male judges ${ }^{8}$. Court officials, women ${ }^{9}$ and other "outsiders", litigants, the diverse audiences of the law beyond the judiciary and lawyers, legal communications and legal objects ${ }^{10}$ have tended to receive short shrift. While the history of law firms

\footnotetext{
${ }^{4}$ R. F. V. Heuston, Lives of the Lord Chancellor, 1885-1940 (Oxford, Oxford University Press, 1964) and Lives of the Lord Chancellors, 1940 - 1970 (Oxford, Oxford University Press, 1987); Robert Stevens, Law and Politics: the House of Lords as a Judicial Body, 1800 - 1976 (London, Weidenfeld and Nicolson, 1979).
}

${ }^{5}$ R. Auchmuty, "Whatever happened to Miss Bebb?: Bebb v The Law Society and women's legal history", (2011) 31 Legal Studies 199-230; J. Beatson and R. Zimmermann, (eds.), Jurists Uprooted: German-Speaking Émigré Lawyers in Twentieth Century Britain (Oxford: Oxford University Press, 2004); Ruth Dukes, "Constitutionalizing employment relations; Sinzheimer, Kahn-Freund, and the role of labour law" (2008) 35) Journal of Law and Society 341- and "Otto Kahn-Freund and Collective Laissez-Faire: An Edifice without a Keystone?" (2009) 72 Modern Law Review 220-246; Nicola Lacey, A Life of HLA Hart, The Nightmare and the Noble Dream (Oxford: Oxford University Press, 2004); R. Gwynedd Parry, David Hughes Parry - A Jurist in Society, (Cardiff: University of Wales Press, 2010); Neil Duxbury, Frederick Pollock and the English Juristic Tradition (Oxford: Oxford University Press, 2004); W. R. Prest, William Blackstone : law and letters in the eighteenth century (Oxford, Oxford University Press, 2008).

\footnotetext{
${ }^{6}$ http://www.Ise.ac.uk/collections/law/projects/legalbiog/lbp.htm

${ }^{7}$ Eminent Scholars Archive (University of Cambridge) http://www.squire.law.cam.ac.uk/eminent_scholars/
}

${ }^{8}$ Only a relatively small number of judges have been the subject of sustained, modern biographies: see Patrick Polden, "Judging Judges. The Reputations of Nineteenth-Century Judges and their Sources", in Anthony Musson and Chantal Stebbings (ed)., Making Legal History. Approaches and Methodologies (Cambridge: Cambridge University Press, 2012) 53-71.

${ }^{9}$ Cf. R. Auchmuty, "Whatever happened to Miss Bebb?", ibid and "Early women law students at Cambridge and Oxford", (2008) Journal of Legal History 63-97; P. Polden, "Portia's progress: women at the bar in England, 1919-1939", (2005) 12 International Journal of the Legal Profession, 293-338. Women have received more sustained attention in Canada and the United States.

${ }^{10} \mathrm{Cf}$. David Sugarman, "Beyond Ignorance and Complacency: Robert Stevens' Journey Through Lawyers and the Courts", (2009) 16 International Journal of the Legal Profession 7-31 (which is a 
has added considerably to our understanding of legal practice, and the inter-play between the public sphere and the private sphere in legal life ${ }^{11}$, the impact of these histories has been largely confined to the realm of business history. Echoing legal history in general, the approaches adopted, and the source material utilised, by legal biography, fetishize texts. Approaches and sources tend to be less diverse than the best of contemporary life writing. Important sources - such as autobiography, obituaries and eulogies, advertisements, oral history ${ }^{12}$, visual material ${ }^{13}$ and objects

biography of a book about law); Neil MacGregor, A History of the World in 100 Objects (London, Allen Lane, 2010).

${ }^{11}$ See, for example, J. Slinn, A History of Freshfields (London 1984), and idem, Linklaters and Paines: The First 150 Years (London, 1987); V. Belcher, Boodle, Hatfield and Co. (London, 1985); L. Dennett, Slaughter and May (London, 1989); W. Cobb, A History of Grays of York (York, 1989); P. Davis, Number 1 (London, 1984); J. Scott, Legibus: King, Thorne and Stace (London, 1980); A. Thirlwell, A Century of Practice: Isadore Goldman and Son (London, 1985); C. Jackson, A Cambridge Bicentenary: The History of a Legal Practice, 1789-1989 (Bungay, 1990). For a useful overview of this new field see J. Slinn, "The Histories and Records of Firms of Solicitors," (1989) 22 Business Archives 58.

${ }^{12}$ Cf. David Sugarman, "In His Own Voice: H.L.A. Hart in Conversation with David Sugarman". Online blog published by Oxford University Press to accompany the publication of the online audio interview, "Hart Interviewed: H.L.A. Hart in Conversation with David Sugarman". The interview is broken down into nine parts, available for streaming and download

http://blog.oup.com/2012/12/h-I-a-hart-in-conversation-with-david-sugarman/

http://www.oup.co.uk/academic/law/hart/

The interview is also accessible via the YouTube playlist.

http://www.youtube.com/playlist?list=PL3MAPgqN8JWiLdUqgmrQMzhao6b-RrS49.

The text of most of the interview was originally published as "Hart Interviewed: H.L.A. Hart in Conversation with David Sugarman" (2005) 32 Journal of Law and Society 267-293.

${ }^{13}$ Cf. J. H. Baker, "History of the Gowns worn at the English Bar." (1975) 9 Costume 15-; R. Evans, The fabrication of virtue: English prison architecture 1750 -1840 (Cambridge, Cambridge University Press, 1982); H. T. Dickinson, Caricatures and the Constitution. (Cambridge, Chadwyck-Healey, 1986); Alan Hunt, Governance of the Consuming Passions: A History of Sumptuary Regulation (London, Macmillan, 1995); C. Douzinas and L. Nead, eds., Law and the Image: The Authority of Art and the Aesthetics of Law (Chicago, University of Chicago Press, 1999); D. Evans, "Theatre of Deferral: The Image of the Law and the Architecture of the Inns of Court." (1999) 10 Law \& Critique 125; Linda Mulcahy, Legal Architecture: Justice, Due Process and the Place of Law (Oxford, Routeldge, 2001); Clare Graham, Ordering Law: the Architectural and Social History of the English Law Court to 1914 (Aldershot, Ashgate Publishing, 2003); P. Raffield, Images and Cultures of Law in Early Modern England: Justice and Political Power, 1558-1660 (Cambridge, Cambridge University Press, 2004); David Sugarman, "Images of Law. Legal Buildings, 'Englishness' and the Reproduction of Power". In R. Schulze (ed.) Rechtssymbolik und Wertevermittlung (Berlin: Duncker \& Humblot, 2004) 194-225; Leslie Moran, "Judging Pictures: A Case Study of Chief Justices, Supreme Court of New South Wales", (2009) 5 International Journal of Law in Context 255-314; Peter Goodrich, "Specters of Law; Why the History of the Legal Spectacle has Not Been Written", (2011) 1 UC Irvine 
- are frequently neglected ${ }^{14}$. The physical and sensory textures of everyday legal life ${ }^{15}$ receive scant attention. Consequently, legal biography has been largely cut-off from, and seen as irrelevant to, intellectual, social and pictorial history, and the "humanities turn" in socio-legal scholarship ${ }^{16}$.

Like all historical writing, legal biography is an epistemologically problematic endeavour. While some biographical source material will be readily available, other material may be fragmentary, elusive, scattered and unreliable. Legal life writing takes us into a realm of evidential and interpretative uncertainty normally beyond the comfort zones of those trained in the certainties of lawyers. The connections, if any, between source material and legal lives, are invariably complex and contradictory, and usually open to a welter of interpretations.

Moreover, legal biography may not be good for your academic career. At its best, legal life writing is labour-intensive and, therefore, expensive, like works of outright history. It fits ill within the current regime for assessing the quality of research at UK educational institutions. ${ }^{17}$

Law Review 773-812; Anthony Musson, "Visual Sources" in Anthony Musson and Chantal Stebbings (eds.), Making Legal History. Approaches and Methodologies (Cambridge: Cambridge University Press, 2012) 264-283.

${ }^{14}$ Gwynedd Parry's valuable discussion of legal biography neglects these sources; he dismisses autobiography, for example, but with no reasoned argument to support this exclusion: R. Gwynedd Parry, "Is legal biography really legal scholarship?" (2010) 30 Legal Studies 208-229, 209.

15 Cf. Peter Goodrich, "Eating Law: Commons, Common Land, Common Law." (1991) 12 Journal of Legal History 246-267.

${ }^{16}$ For example, the following journals: Yale Journal of Law and the Humanities, founded in 1988; Law, Culture and the Humanities (Sage), founded in 2005; and Law and Humanities (Hart), founded in 2007. There also exists a Law and Humanities blog at http://lawlit.blogspot.co.uk/. See, further, Dermot Feenan, "Foreword: Socio-legal studies and the humanities" (2009) 5 International Journal of Law in Context, 235-242; Melanie L. Williams (2009) "Socio-legal studies and the humanities law, interdisciplinarity and integrity" (2009) 5 International Journal of Law in Context 243-261.

17 This is likely to be the case for UK based scholars given the Research Excellence Framework (REF), the new system for assessing the quality of research at UK educational institutions and the role of 'impact' in assessing research excellence: see http://www.ref.ac.ukl . See, generally, Peter Scott, "Why research assessment is out of control", The Guardian, 4 November 2013. 
Despite its undoubted difficulties, legal life writing provides a vital resource for understanding the ideas and culture of the legal community, and their place within the wider world. In the paper of which this is an abstract I consider why the acceptance of legal life writing has been belated and contested. I also suggest ways of expanding the repertoire of legal biography and, therefore, socio-legal scholarship. I provide insights into "what legal biography adds?" My objective is to support a perspective in the making: a broader, more pluralistic, conception of life writing that transcends the traditional stark dualisms between internal and external legal history $^{18}$, and top-down and bottom-up approaches ${ }^{19}$. I also hope to stimulate the interest of, and engagement with, socio-legal studies (especially those associated with the humanities-turn in socio-legal studies), the law in society movement, as well as the human sciences and even lay audiences.

Professor David Sugarman

Lancaster University Law School, UK

\footnotetext{
${ }^{18}$ On the distinction between internal and external legal history, see Robert W. Gordon, "Introduction: J. Willard Hurst and the Common Law Tradition in American Legal Historiography." (1975) 10 Law and Society Review 9-55.

${ }^{19}$ On "top-down" and "bottom-up" histories see, for example, Geoff Eley, A Crooked Line: From Cultural History to the History of Society (2005); E.P. Thompson, The Essential E. P. Thompson. (2001); Peter N. Stearns, "Social History Present and Future", (2003) 37 Journal of Social History 1-9.
} 